\title{
Surficial Geology and Neotectonics of Selected Areas of Western Idaho and Northeastern Oregon
}

\section{By Stephen F. Personius}

Denver Federal Center

Box 25046, MS 966

Denver, CO 80225

\section{Open-File Report 98-771}

This report is preliminary and has not been reviewed for conformity with U.S. Geological Survey editorial standards or with the North American Stratigraphic Code. Any use of trade, product, or firm names is for descriptive purposes only and does not imply endorsement by the U.S. Government. 


\section{CONTENTS}

Introduction 1

Fault scarp profiles 1

Idaho study areas $\mathbf{4}$

Long Valley 4

Sackung features on West Mountain 4

Meadows Valley 7

Paleolake Meadows 9

Rush Peak area 11

Oregon study area 15

Grande Ronde Valley fault zones 15

West Grande Ronde Valley fault zone 15

Foothill Segment 15

La Grande Segment 19

Eastern splay 20

East Grande Ronde Valley fault zone 21

References 24

\section{ILLUSTRATIONS}

FIGURE

1. Location map of selected fault-controlled valleys in western Idaho and northeastern Oregon 3

2. Plot of all scarp height and slope angle values obtained in this study 5

3. Map of sackung features, vegetation lineaments, and landslide headscarps on West Mountain 6

4. Map of Meadows Valley, showing approximate trace of Meadows Valley fault zone 8

5. Surficial geologic map of the north end of Meadows Valley 10

6. Map of generalized trace of the Rush Peak and Goodrich Creek faults in western Idaho 12

7. Surficial geologic map of the Rush Peak fault at Rush Creek 14

8. Plots of scarp height and scarp-slope angle values for southwest-facing fault scarps in this study 16

9. Map showing generalized traces of the West and East Grande Ronde Valley fault zones 17

10. Surficial geologic map of West Grand Ronde Valley fault zone, La Grande, Oregon 18

11. Plots of scarp height and scarp-slope angle values from eastern splay of $\mathrm{La}$ Grande segment 22

12. Surficial geologic map of East Grand Ronde Valley fault zone in the vicinity of Gasset Bluff 23

\section{TABLES}

1. Time terms for the Quaternary Period used in this report 2

2. Scarp-profile data from faults in western Idaho and northeastern Oregon 2

3. Historic climate data for selected reference and fault scarp profile sites 5 


\section{Surficial Geology and Neotectonics of Selected Areas of Western Idaho and Northeastern Oregon}

\section{By Stephen F. Personius}

\section{INTRODUCTION}

The region described in this report is in an area of complex geology and geomorphology in western Idaho and northeastern Oregon (fig. 1). The western part of the region is underlain by rocks comprising an allochthonous island arc terrane that was accreted to the North American plate during the Cretaceous (Brooks and Vallier, 1978). The eastern part of the region is underlain by granitic and metamorphic rocks of the Cretaceous Idaho Batholith (Armstrong and others, 1977; Vallier and Brooks, 1987). The entire region has subsequently been buried by voluminous flows of Miocene Columbia River Basalt Group basalt (Reidel and Hooper, 1989). Miocene to recent faulting (Hooper and Conrey, 1989) has uplifted the region into a series of dissected plateaus, broken by occasional fault-controlled basins and ranges. The western part of the region is dominated by northwest-trending normal faults (Walker and MacLeod, 1991), and the eastern part of the region is dominated by north-trending normal faults (Mitchell and Bennett, 1979; Fitzgerald, 1981). The northwest-trending structures may form the southeastern end of a right-lateral "megashear" zone known as the Olympic-Wallowa lineament (Mann and Meyer, 1993), although others believe that this apparent alignment of structures is simply a zone of regional crustal weakness reactivated in the contemporary tectonic stress regime (Simpson and others, 1993). This report is focused on the surficial geology and evidence for recent faulting in Meadows Valley, Long Valley, and the Rush Peak area in western Idaho, and the Grande Ronde Valley in northeastern Oregon. The time terms used to described the ages of Quaternary deposits and events in this report are listed in table 1.

\section{FAULT SCARP PROFILES}

Most of the geologic data in this report were obtained using common geologic methods such as surficial geologic mapping, airphoto interpretation, and comparisons of relative soil development. However, fault-scarp profiling is a specialized technique that requires some additional explanation. Scarp-profile data (table 2) are commonly used to evaluate the ages of geomorphic escarpments such as fault scarps. A simple method is to compare scarp-slope and scarp-height measurements to those of scarps of known age (Bucknam and Anderson, 1979). Scarps that plot relatively above regression lines of known age are thought to have a younger age, and those that plot below are thought to be older. One of the most commonly used data sets is from the Bonneville shoreline, a late Pleistocene highstand shoreline of Lake Bonneville in northern Utah. In this study, two sets of scarp data were used for age comparisons: data from the Bonneville shoreline (15-16 ka; Scott and others, 1983; Currey, 1990) and data from fluvial scarps of varying aspect in central Idaho (15 $\pm 4 \mathrm{ka}$; Pierce and Colman, 1986).

Fault scarps obviously form under different processes than fluvial and shoreline scarps, but the processes that modify them after formation are thought to be similar (Pierce and Colman, 1986). One significant difference is that fault scarps, especially those that are more than $2-4 \mathrm{~m}$ high, usually form as a result of repeated surface-faulting events that may be separated in time by hundreds to thousands of years. This rejuvenation of fault scarps formed by multiple events tends to create scarps that have steeper scarp-slope angles, and hence younger morphologic ages, than their total scarp 
TABLE 1. Time terms for the Quaternary Period used in this report, modified from Morrison (1991) and Izett and Obradovich (1994).

\begin{tabular}{ll}
\hline \multicolumn{1}{c}{ Subdivision } & Time Span \\
\hline Holocene & present to $10 \mathrm{ka}$ \\
latest Pleistocene & $10 \mathrm{ka}$ to $\sim 28 \mathrm{ka}$ \\
late Pleistocene & $10 \mathrm{ka}$ to $\sim 128 \mathrm{ka}$ \\
middle Pleistocene & $\sim 128 \mathrm{ka}$ to $770 \mathrm{ka}$ \\
early Pleistocene & $770 \mathrm{ka}$ to $1650 \mathrm{ka}$ \\
late Quaternary & present to $\sim 128 \mathrm{ka}$ \\
Quaternary & present to $1650 \mathrm{ka}$ \\
\hline
\end{tabular}

TABLE 2. Scarp-profile data from faults in western Idaho and northeastern Oregon. See figures 2, 8, and 11 for data plots, and figures 7,10 , and 12 for profile locations.

\begin{tabular}{lccccccc}
\hline $\begin{array}{l}\text { Profile } \\
\text { Number }\end{array}$ & Fault Name & $\begin{array}{c}\text { Scarp } \\
\text { Azimuth } \\
(9\end{array}$ & $\begin{array}{c}\text { Lower } \\
\text { Slope } \\
\text { Angle }\end{array}$ & $\begin{array}{c}\text { Upper } \\
\text { Slope } \\
\text { Angle }\end{array}$ & $\begin{array}{c}\text { Maximum } \\
\text { Slope Angle }\end{array}$ & $\begin{array}{c}\text { Scarp } \\
\text { Height } \\
(\mathrm{m})\end{array}$ & $\begin{array}{c}\text { Surface } \\
\text { Offset } \\
(\mathrm{m})\end{array}$ \\
\hline RC94-1 & Rush Peak & 222 & 3.0 & 7.0 & 15.0 & 7.3 & 4.9 \\
ZW-I* & Rush Peak & 155 & 4.5 & 8.5 & 17.5 & 7.3 & 4.4 \\
ZW-I* & Rush Peak & 195 & 5.5 & 5.0 & 16.4 & 10.4 & 6.9 \\
& W. Grande Ronde & 50 & 8.5 & 11.0 & 27.0 & 12.0 & 8.2 \\
LGW94-1 & W. Grande Ronde & 85 & 10.0 & 11.5 & 24.0 & 11.3 & 6.8 \\
LGW94-2 & E. Grande Ronde & 250 & 13.0 & 18.0 & 25.5 & 13.9 & 6.0 \\
LGE94-1 & E. Grande Ronde & 250 & 13.5 & 18.5 & 28.5 & 23.2 & 10.8 \\
\hline
\end{tabular}

*Scarp parameters measured from published scarp profiles (Zollweg and Wood, 1993, their figs. 2-11, 2-12) by the author. 


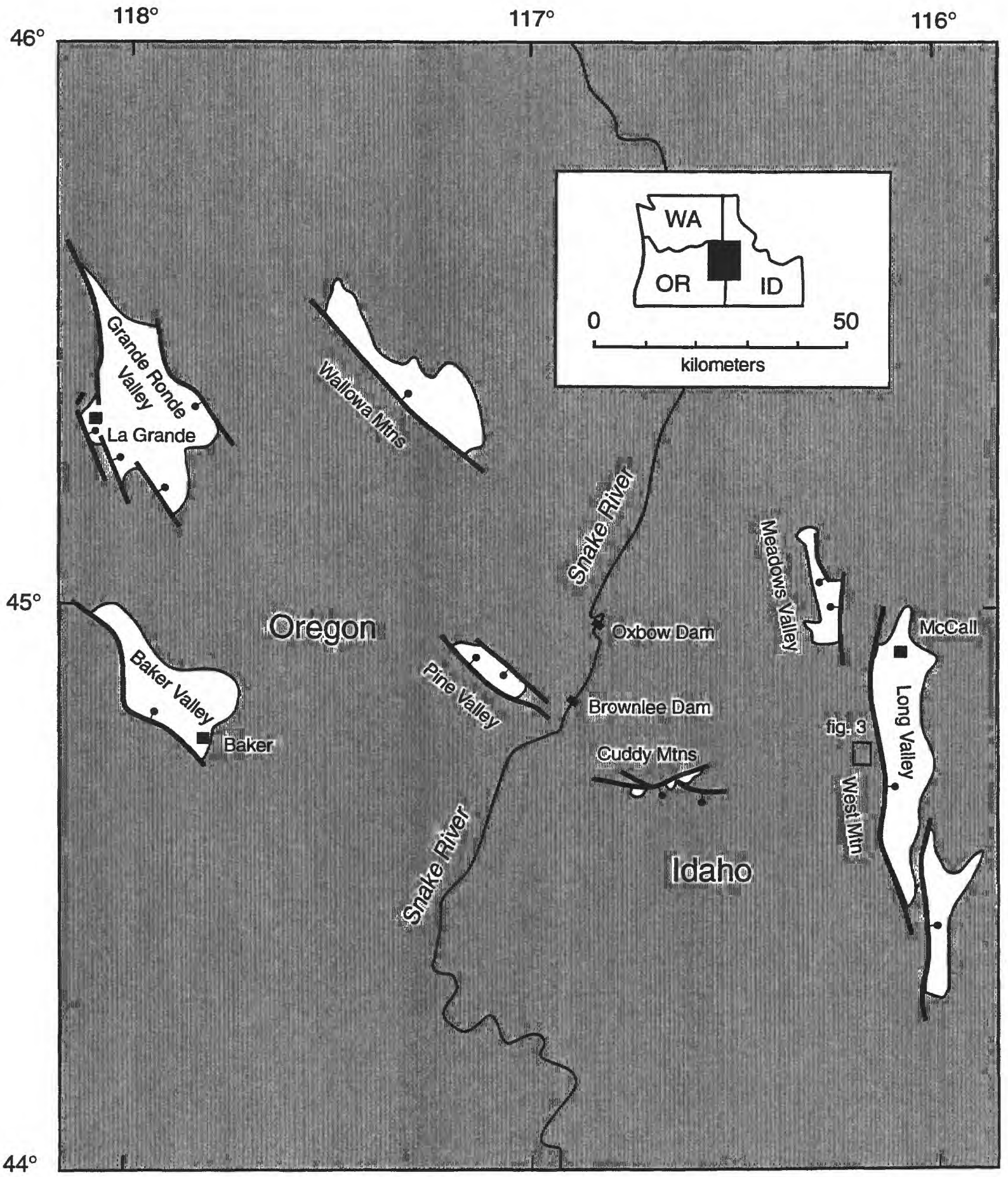

FIGURE 1. Location map of selected fault-controlled valleys in western Idaho and northeastern Oregon. Unshaded areas are Quaternary valley-fill deposits. 
height would suggest. Thus plots of scarps with heights greater than $-4 \mathrm{~m}$ should be considered maximum morphologic ages for the youngest event recorded by these scarps.

The plots of the data points as well as the spacing between the linear regressions fit to the reference data are useful in describing the precision of scarp-profile methods (fig. 2). The wide scatter evident in data from scarps of nearly identical age is a reflection of variations in rates of scarp modification related to differences in scarp materials, aspect, microclimate, and macroclimate. Ideally, the best scarp profile comparisons are made to reference scarps of similar aspect formed in similar materials and environments (Pierce and Colman, 1986). Unfortunately, no reference scarp data are available that exactly match the climate of the sites examined in this study (table 3). However, at least in the case of the central Idaho data, scarps can be sorted with respect to aspect (fig. 2) to reduce the effects of microclimate on rates of scarp modification (Pierce and Colman, 1986). Given these caveats, comparisons between fault scarps and the reference scarps from central Idaho and north-central Utah probably are useful in providing reasonable relative age information.

\section{IDAHO STUDY AREAS Long Valley}

Long Valley is a large, north-trending intermontane basin in western Idaho (fig. 1). A large displacement ( $-3 \mathrm{~km}$; Kinoshita, 1962, Schmidt and Mackin, 1970), down-to-the-east normal fault on the western side of Long Valley forms the steep eastern flank of West Mountain. The east side of Long Valley probably is controlled by west-dipping normal faults of lesser displacement, but the gentle, embayed slopes on this side of the valley and strong westward tilt of rocks in the valley (Schmidt and Mackin, 1970, p. 5) indicate that these faults are less active than the dominant faults on the west side of Long Valley. The Long Valley fault system has been examined for evidence of Quaternary movement by numerous investigators (Gilbert and others, 1983; Geomatrix Consultants, 1989; Zollweg and Wood, 1993), but no conclusive evidence of fault scarps in Quaternary deposits has been found. I found no evidence of late Quaternary movement along this fault system, although most of the mountain front is steep, heavily forested, and obscured in places by large landslides. Timber Ridge glacial deposits, which are thought to be equivalent to Bull Lake deposits in the Rocky Mountains, appear to lie unfaulted across the fault zone southwest of McCall (Schmidt and Mackin, 1970; Colman and Pierce, 1986). Thus the latest movement on the Long Valley fault system probably predates the 140-150 ka age of these deposits (Colman and Pierce, 1986).

\section{Sackung Features on West Mountain}

Extensive large landslides are present along the east flank of West Mountain in the vicinity of No Business Mountain, on the west side of Long Valley (P.E. Carrara, oral commun., 1995). Several examples of trench or graben-like surficial features thought to be sackungen are present along the crest of West Mountain just west of these large landslides (fig. 3). These features comprise a northeast-trending zone about $1 \mathrm{~km}$ wide by $2 \mathrm{~km}$ long. Most of these features have little relief and consist of vegetation lineaments or linear contacts between bedrock and soil-and sediment-filled meadows. The underlying bedrock is predominantly Cretaceous metamorphic and granitic rocks of the Idaho Batholith (Mitchell and Bennett, 1979; Fitzgerald, 1981). In a few places, the foliation and bedding in these rocks is roughly parallel to the trends of sackungen, indicating that pre-existing bedrock attitudes are controlling sackung orientation. In a few locations, the sackungen form grabens with up to several meters of relief in surficial deposits. Some sackungen are the loci of ephemeral springs, which are probably caused by bedrock control of shallow groundwater systems.

The origin of the sackung features on West Mountain is unknown, but studies elsewhere in mountainous areas of western North America suggest several possibilities. Some studies suggest that sackung features are directly related to tectonic activity (e.g. Solonenko, 1977; Morton and others, 1989), but many studies relate sackung features to large-scale gravitational spreading of mountainous terrain (Radbruch-Hall and others, 1976; Bovis, 1982; Varnes and others, 1989; Clague and Evans, 1994; McCalpin and Irvine, 1995). The presence of Pinedale-aged cirques (Carrara and Doerner, 
TABLE 3. Historic climate data (Western Regional Climate Center, unpublished web site data, 1997) for selected reference and fault scarp profile sites.

\begin{tabular}{llcc}
\hline Scarp Location & Climate Data Location & MAT $\left({ }^{\circ} \mathrm{C}\right)^{1}$ & MAP $(\mathrm{cm})^{2}$ \\
\hline${ }^{3}$ Lake Bonneville, UT & Delta, UT & 10.1 & 19.8 \\
${ }^{3}$ Lake Bonneville, UT & Richfield, UT & 9.4 & 21.1 \\
& & 5.5 & 25.9 \\
${ }^{3}$ Central ID & Arco, ID & 5.5 & 24.8 \\
${ }^{3}$ Central ID & Mackay, ID & 8.8 & 50.8 \\
Rush Peak, ID & Cambridge, ID & 9.1 & 67.3 \\
Rush Peak, ID & Council, ID & 9.4 & 44.4 \\
La Grande, OR & La Grande, OR & 8.8 & 35.1 \\
La Grande, OR & Union, OR & & \\
\hline
\end{tabular}

${ }^{1}$ Mean annual temperature

${ }^{2}$ Mean annual precipitation

${ }^{3}$ Reference scarps

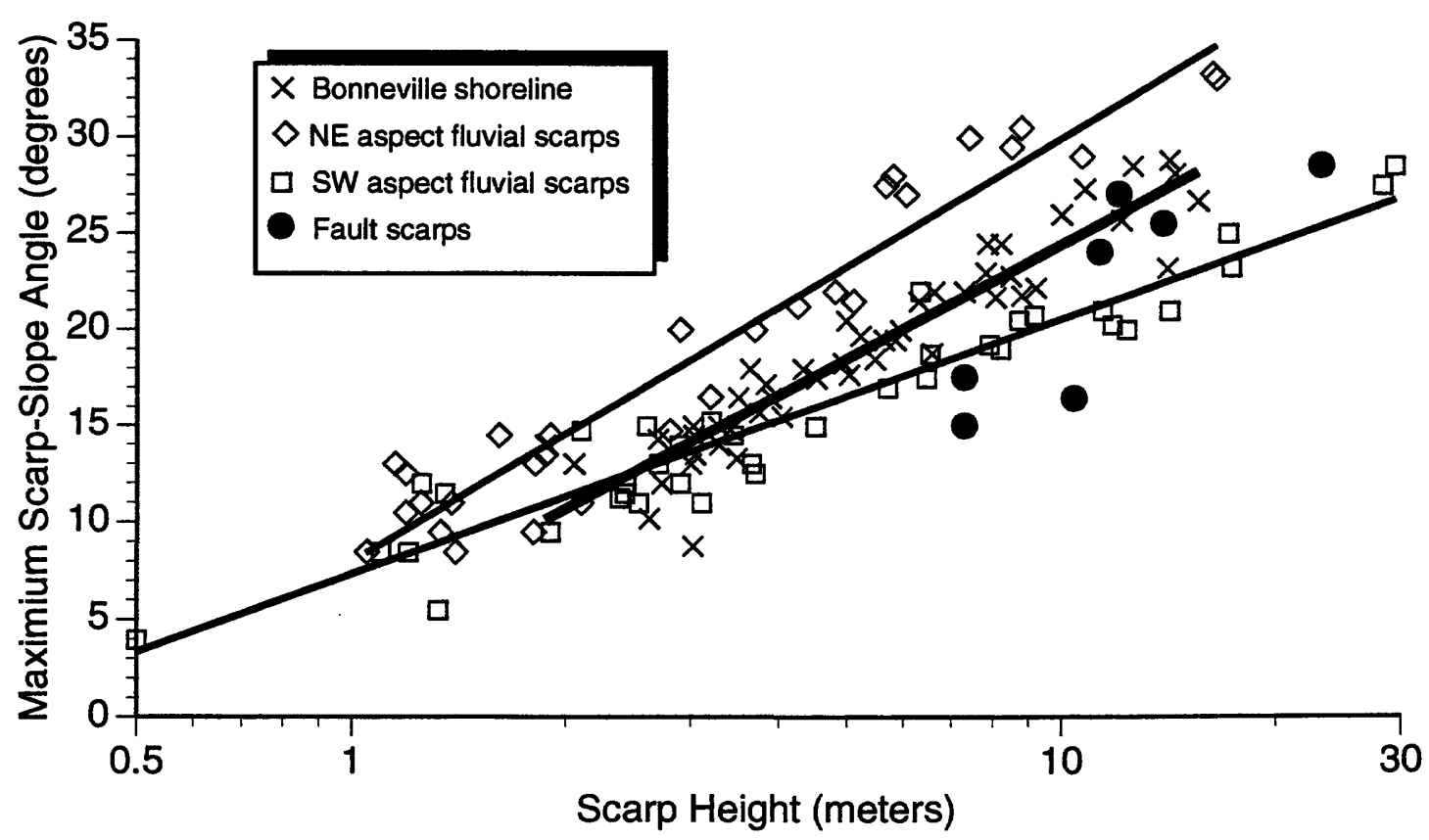

FIGURE 2. Plot of all scarp height and slope angle values obtained in this study. Three solid lines are linear regressions of plotted data from three reference scarps: profiles of Bonneville shoreline in central Utah (15-16 ka; age from Scott and others, 1983 and Currey, 1990; data from R.C. Bucknam, pers. comm., 1996); profiles of northeast and southwest-facing fluvial scarps in Big Lost River Valley, central Idaho (15 \pm 4 ka; age and data from Pierce and Colman, 1986). Note the wide point scatter between all three $15 \mathrm{ka} \mathrm{refer-}$ ence lines. Scarps that plot significantly above the regression lines suggest relative ages that are younger than the reference scarps; scarps that plot significantly below the regression lines suggest relative ages that are older than the reference scarps. Larger fault scarps ( $>4 \mathrm{~m}$ in height) probably are formed by multiple events and thus yield maximum morphologic ages. 


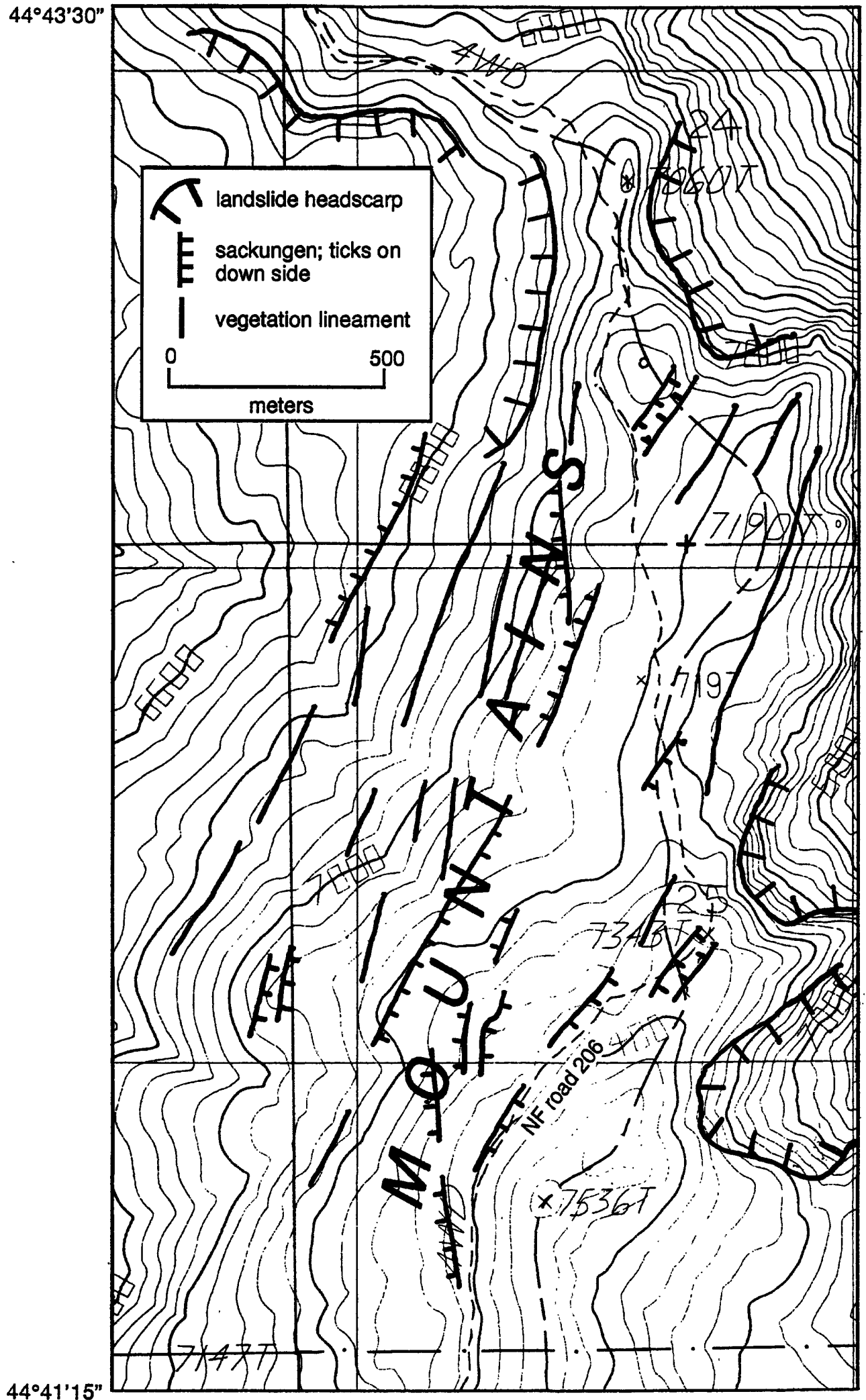

FIGURE 3. Map of sackung features, vegetation lineaments, and landslide headscarps on West Mountain, west flank of Long Valley; see figure 1 for location. 
1996) and large landslides on the steep eastern flank of West Mountain support the hypothesis that these sackung features are related to slow gravitational movements related to glacial and/or landslide erosion, rather than tectonic activity. The presence of sackungen on the gentler west flank, rather than the steeper east flank of West Mountain appears to be anomalous, but similar relations in many places in the western United States led Varnes and others (1989, p. 18) to speculate either that such sackungen are related to greater remaining mass (and thus higher gravitational stresses) on the gentler slopes, or that any sackungen formed on the steeper flanks have been removed or obscured by erosion.

The ages of the West Mountain sackung features are unknown, but several aspects of the geomorphology of the area give clues to their ages and rates of activity. The west flank of West Mountain is covered by a thick (up to a meter) blanket of late Quaternary loess; some of this silty sediment has partially to completely filled some of the sackung grabens. In several bogs in cirques along the east flank of West Mountain, this loess overlies sediments containing Glacier Peak tephra.

Radiocarbon assays on woody materials and organic sediment overlying the tephra and underlying the loess yield ages of 10-12 ka (Carrara and Doerner, 1996), If the West Mountain sackung features formed in response to glacial unloading and landsliding related to deglaciation, then these features probably were initially formed in very latest Pleistocene time. Although the presence of several meters of relief on some sackung scarps indicate repeated movement in the Holocene, few of the sackung features have the fresh appearance of very young sackungen described in similar settings elsewhere (e.g. Varnes and others, 1989; Clague and Evans, 1994). The relatively subdued appearance of the West Mountain features may be a result of slower rates of slip in the Holocene, as has been documented in recent detailed sackung investigations in Colorado (McCalpin and Irvine, 1995).

\section{Meadows Valley}

Meadows Valley is a small, north-trending intermontane basin located a few kilometers northwest of McCall, Idaho (fig. 1). The valley resembles a half graben, with an embayed, gently sloping western margin and a steep eastern margin, but north-trending normal faults offset Columbia River Basalt Group basalt and granitic rocks of the Idaho Batholith along both valley margins (Fitzgerald, 1981). The steep eastern flank of Meadows Valley appears to be controlled by a north-trending, downto-the-west normal fault zone (herein informally termed the Meadows Valley fault zone), but bedrock knobs on the valley floor suggest little sediment accumulation in the graben and relatively small total displacements across the range-bounding fault zones (fig. 4).. The Meadows Valley fault zone may be best expressed in the southern part of the valley, where weakly developed faceted spurs in basaltic bedrock mark the probable fault trace along the eastern valley margin from Fourmile Creek southward to south of Goose Creek. North of Fourmile Creek, the fault zone steps westward about $1 \mathrm{~km}$, loses any evidence of facets, and decreases in displacement as it trends northward to the head of Meadows Valley. This section of the fault zone is developed mostly in granitic rocks.

Photo reconnaissance and field investigations yielded no evidence of faulting in Quaternary deposits along the Meadows Valley fault zone. For example, the Pinedale-equivalent glacial outwash fan present where Goose Creek enters Meadows Valley (Othberg, 1982) lies unfaulted across the trace of the Meadows Valley fault zone.

Stratigraphically equivalent Pilgrim Cove and McCall moraines and outwash in Long Valley a few kilometers to the east are thought to have formed 14-20 ka (Colman and Pierce, 1986), so faulting on the Meadows Valley fault zone must predate the age of these deposits. Older alluvial fan remnants and landslides also lie unfaulted across the trace of the Meadows Valley fault zone. Unfaulted older fan remnants are present at Sixmile and Fourmile Creeks, and large landslides are deposited across the fault trace north of Sixmile Creek and south of Goose Creek (fig. 4). The ages of these deposits are unknown, but well developed reddish soils (5YR and 7.5 YR hues) on some of these deposits are similar to or better developed than soils on 140-150 ka Bull Lake-equivalent Timber Ridge deposits in Long Valley (Colman and Pierce, 1986). Such correlations indicate that latest movement on the Meadows Valley fault zone predates $140 \mathrm{ka}$. 


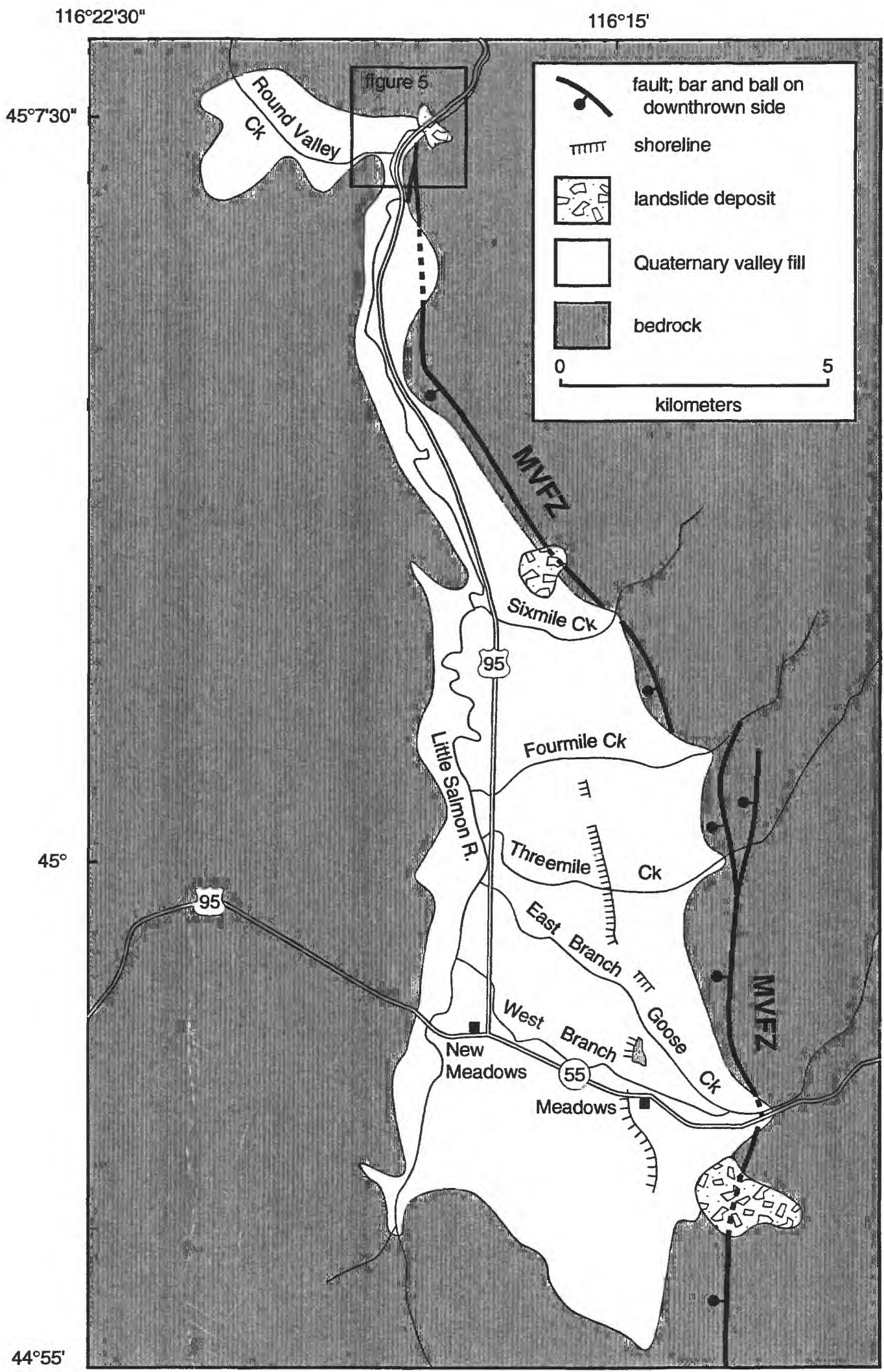

FIGURE 4. Map of Meadows Valley, showing approximate trace of Meadows Valley fault zone, locations of selected Quaternary deposits, and shoreline features related to a paleolake Meadows. 
One strand of the Meadows Valley fault zone is exposed in a roadcut near the northern end of Meadows Valley. A normal fault zone is exposed in a U.S. Highway 95 roadcut about $600 \mathrm{~m}$ northeast of the confluence of Round Valley Creek and the Little Salmon River. The fault dips steeply to the west and downfaults Miocene Imnaha or Grande Ronde Member basaltic palagonitic tuffs against Cretaceous granitic rocks. A 2-m-thick wedge of stratified sandy gravel lies unfaulted in the fault zone at the top of the exposure. These sediments are too well sorted and stratified to be hillslope colluvium, so they probably are related to fluvial deposition when the Little Salmon River stood at a higher terrace level. Old fluvial terrace remnants are present at similar elevations (15-20 m above stream level) about $2 \mathrm{~km}$ south of the fault exposure. The age of these unfaulted deposits is unknown, but their height above the present river level indicate a pre-last glacial age, and thus support the interpretation that the latest movement on the Meadows Valley fault zone predates the latest Pleistocene.

\section{Paleolake Meadows}

\footnotetext{
Although no evidence of late Quaternary faulting was found along the eastern margin of Meadows Valley, remnants of a several-kilometerlong, northwest-trending, west-facing 1- to 5-mhigh scarp were identified in Pinedale-equivalent alluvial deposits on the valley floor near the town of Meadows (fig. 4). These scarps roughly parallel the N-S structural grain in the region (Fitzgerald, 1981), but everywhere these features are preserved, they lie at similar elevations of $1207 \pm 5 \mathrm{~m}$. The restriction of these scarps to a narrow elevation range, along with several other lines of evidence discussed below, indicate that these features are the remnants of a shoreline or shorelines formed by a temporary lake, rather than a fault scarp.

The existence of paleolake Meadows is supported by several features found at the north end of Meadows Valley (fig. 5). At its extreme northern end, the valley constricts to a narrow canyon cut by the Little Salmon River. At this constriction, landslide deposits are present on both sides of the river, and a prominent U-shaped headscarp is located on the southeast side of the river. The presence of
}

thick (>50 m) landslide deposits at this constricted location indicates that the landslide must have at least temporarily dammed the Little Salmon River. The landslide remnants adjacent to the river reach maximum elevations of $-1200-1215 \mathrm{~m}$. Although the elevation of the top of the landslide at the present location of the Little Salmon River cannot be determined, the similarity between the elevations of the preserved parts of the landslide and the shoreline scarps in the southern part of the valley support a landslide dam/lacustrine origin for these features. Several bench-like platforms cut into the upstream side of the landslide remnant on the northwest side of the river also appear to be wavecut features. If paleolake Meadows reached a maximum elevation of $-1207 \mathrm{~m}$, then the lake had a maximum depth of $-55 \mathrm{~m}$ at its deepest point near the landslide, and was $-28 \mathrm{~m}$ deep at the present location of the town of New Meadows.

Evidence of catastrophic failure of the Meadows Valley landslide dam can be found downstream for several kilometers along the Little Salmon River. Directly downstream of the landslide, the gentle gradient $(0.8 \mathrm{~m} / \mathrm{km})$ and meandering channel pattern of the river in Meadows Valley is replaced by a straight, incised channel with numerous rapids and small waterfalls. The bed of the river in this incised reach drops about $15 \mathrm{~m}$ in $100 \mathrm{~m}$ (gradient of $150 \mathrm{~m} / \mathrm{km}$ ), and for the next -3 $\mathrm{km}$, the channel has been scoured to bedrock and has a gradient of $28 \mathrm{~m} / \mathrm{km}$. From the scoured reach downstream to the confluence with the Salmon River ( -35 river $\mathrm{km}$ ), the Little Salmon River has a gradient of $16 \mathrm{~m} / \mathrm{km}$. For several kilometers downstream of the scoured reach, bouldery flood alluvium with clasts of several meters maximum dimension is present on -5 -m-high terraces adjacent to the present channel of the Little Salmon River. The location and height of these terraces are similar to Pinedale-equivalent outwash deposits adjacent to Goose Creek at the southern end of Meadows Valley (Othberg, 1982).

The duration of paleolake Meadows is unknown, but the apparent restriction of most shoreline features to the southeastern part of the valley indicates both a probable westerly paleowind direction and a short lake life span. A short duration is also implied by the lack of significant lacus- 


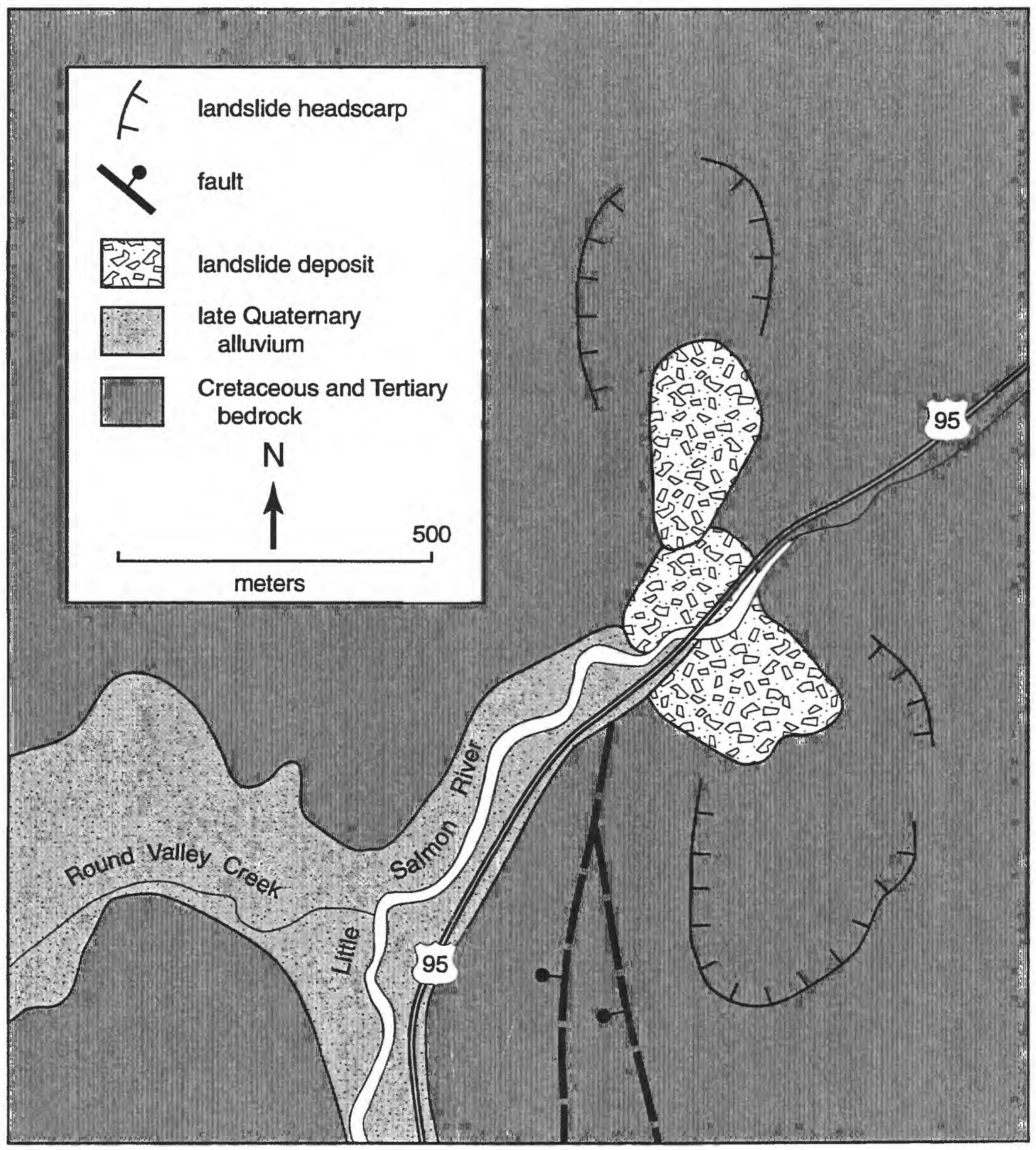

FIGURE 5. Surficial geologic map of the north end of Meadows Valley; see figure 4 for location. Note location of landslide deposits at constriction of Little Salmon River. The large landslide originating on the southeast side of the river probably dammed the river and caused a lake to back up into Meadows Valley in the latest Pleistocene or early Holocene. 
trine deposits in the valley; no clearly identified lacustrine sediments or evidence of small deltas on tributaries were found during my investigations in Meadows Valley. Given the notoriously unstable nature of most historic landslide dams (Costa and Schuster, 1991) and the relatively small size of the Meadows Valley landslide dam, a maximum duration of a few years to a few tens of years is a reasonable estimate.

The age of the landslide and lake in Meadows Valley is poorly constrained. The shoreline clearly cuts Pinedale-equivalent alluvium near the town of Meadows, and flood alluvium from the failure of the landslide dam was deposited on terraces along the Little Snake River that may also be of Pinedale age. Thus both the landslide damburst flood and shoreline evidence indicate a postPinedale age for these features. Pinedale-equivalent outwash deposits in nearby Long Valley are thought to be $14-20 \mathrm{ka}$ (Colman and Pierce, 1986), so the landslide and lake at a maximum are very latest Pleistocene or Holocene in age. A minimum age cannot be determined at present. No definitive lacustrine deposits have been found, so their stratigraphic and chronologic significance cannot be evaluated. Ages of lake highstands have been estimated elsewhere by comparing shoreline morphology to similar features of known age (e.g. Hanks and Wallace, 1985), but the shoreline in Meadows Valley is too poorly preserved for such studies to be conducted. However, where Meadows Valley shoreline remnants are preserved and unmodified by human disturbance, these features do not have the fresh, youthful appearance characteristic of late Holocene fault or fluvial scarps in the western U.S. In addition, no remnants of the shoreline are preserved in Holocene alluvium along the East or West branches of Goose Creek. Thus the morphology and poor preservation indicate that the landslide and lake probably did not form in the last few thousand years. Paleoclimatic studies in the northern Rockies indicate that the period following deglaciation in latest Pleistocene and early Holocene time was characterized by climatic and landscape instability (e.g., Barnosky and others, 1987). Such conditions were conducive to landsliding throughout the region, so the Meadows Valley landslide and paleolake probably occurred during this time period.

\section{Rush Peak Area}

The Rush Peak fault forms the unusual eastwest trending southern margin of the Cuddy Mountains in western Idaho (fig. 1). This area has been the subject of several geologic investigations (Fitzgerald, 1981; Mann and Meyer, 1993; Zollweg and Wood, 1993); much of the recent interest in the region is focused on potential earthquake hazards to nearby large dams on the Snake River. The Rush Peak fault displaces Miocene Columbia River Basalt against Mesozoic intrusive and metamorphic rocks in a down-to-the-south sense of displacement (Fitzgerald, 1981). Mann and Meyer (1993) discuss map patterns they interpret as evidence of substantial left-lateral displacement on the Rush Peak fault, but Zollweg and Wood (1993, p. 2-35) found little evidence to support this interpretation. Following Zollweg and Wood (1993), I found no consistent sense of lateral displacement of stream drainages, and the sinuous trace of the Rush Peak fault does not exhibit the near-vertical dip pattern characteristic of typical strike-slip faults (fig. 6). I conclude that the geomorphic expression of the Rush Peak fault is consistent with primarily normal, down-to-the-south displacement. My reconnaissance examinations of numerous faults in westernmost Idaho are consistent with the results of Zollweg and Wood (1993), who concluded that evidence of late Quaternary surface faulting near the Snake River is restricted to the Rush Peak fault.

The late Cenozoic history of the Rush Peak fault may be best expressed at Rush Creek, where Zollweg and Wood (1993) measured 550-730 m of offset of Miocene Columbia River basalt and 4-7 m of offset of Quaternary alluvium. My reconnaissance mapping (fig. 7) shows that the Rush Peak fault cuts probable latest Pleistocene stream and fan alluvium at Rush Creek. This age assignment is based on the geomorphic position of faulted alluvial deposits, which are found immediately adjacent to Rush Creek and only 5-8 meters above the elevation of the present channel bottom. In addition, a shallow soil pit dug on a faulted alluvial fan about $200 \mathrm{~m}$ east of Rush Creek revealed a poorly developed $\mathrm{A} / \mathrm{Bw} / \mathrm{C}$ soil profile that is consistent with soils on last-glacial Pilgrim Cove (Pinedale-equivalent) deposits in nearby Long Valley, $50 \mathrm{~km}$ to the east (Colman and Pierce, 1986). The Rush Peak 


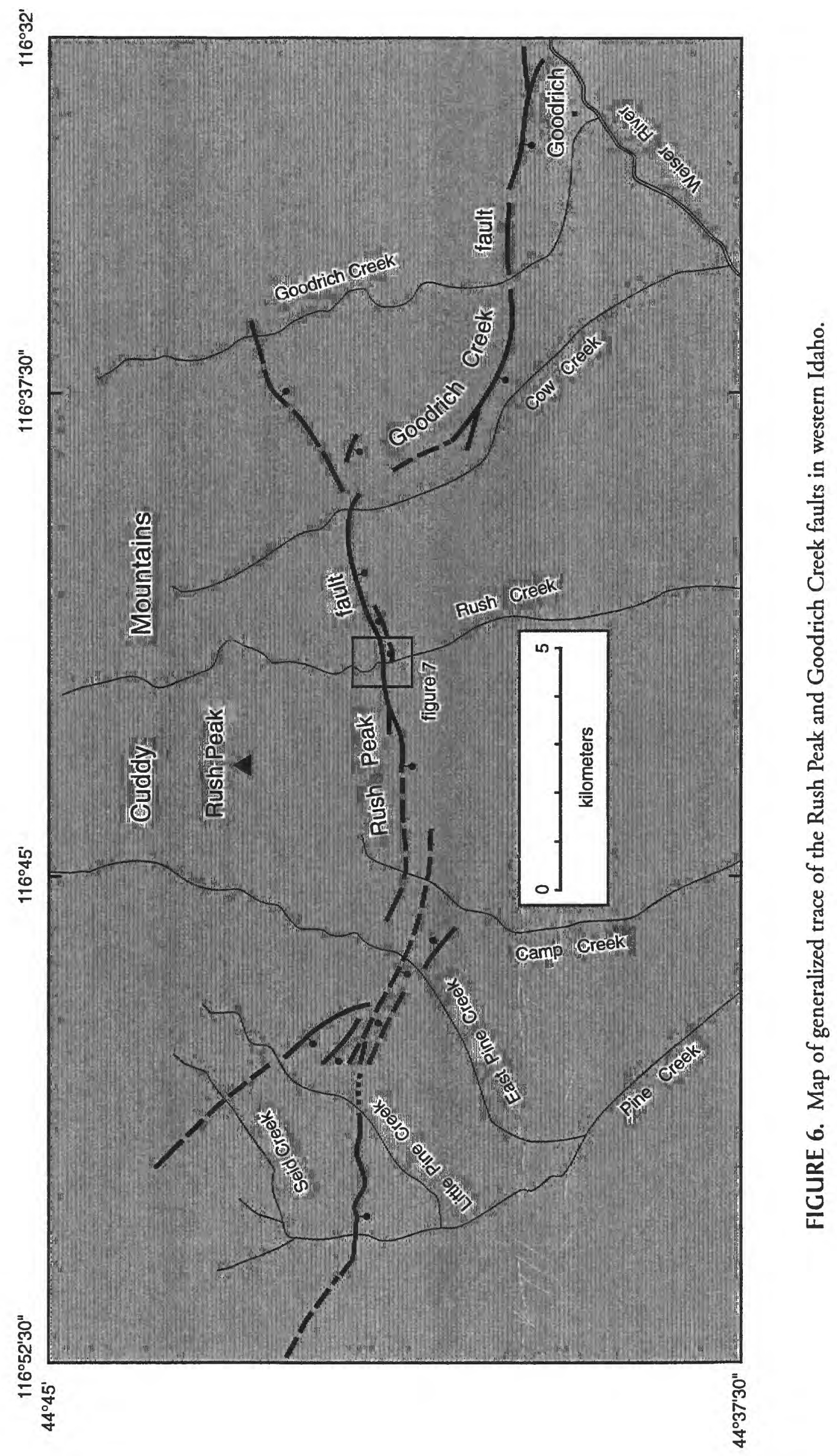


fault clearly offsets these deposits 4-7 $\mathrm{m}$ on the east side of Rush Creek. If this age assignment is correct, then the presence of scarps across these deposits indicates one or more surface-faulting events since the latest Pleistocene.

The scarp-profile data from this area also may support a latest Pleistocene age for surface faulting on the Rush Peak fault. Limited profile data from Zollweg and Wood (1993, their fig. 2-12) and my study plot slightly below the $15 \mathrm{ka}$ reference lines (fig. 8), which might suggest that the scarps are older than $15 \mathrm{ka}$. Zollweg and Wood (1993, p. 235) used this relationship to infer an age of faulting of $10 \mathrm{ka}$ to $100 \mathrm{ka}$. However, given the wide scatter in the original data used to calculate the regression lines (fig. 2) and the likely recurrent nature of the Rush Peak fault scarps, the profile data probably indicate a maximum morphologic age. If the offset alluvium at Rush Creek is equivalent to or younger than last-glacial Pilgrim Cove deposits in the $\mathrm{McC}$ all area, then the latest faulting events must have occurred $<20 \mathrm{ka}$. Measured offsets of 4-7 m yield post-latest Pleistocene (14-20 ka) slip rates of $-0.2-0.5 \mathrm{~mm} / \mathrm{yr}$.

The complex pattern of the Rush Peak fault trace makes determining the length of the fault problematic (fig. 6). The central 9-km-long section of the fault is easily traced mostly as a single ENEtrending fault, with an intermittently present 100 $\mathrm{m}$-wide graben. However, the fault appears to splinter into Y-shaped branches at both its eastern and western ends (Fitzgerald, 1981; Zollweg and Wood, 1993). At the eastern end of the central section, scarps are present on late Pleistocene alluvium just east of Cow Creek, where the fault abruptly turns to the southeast and dies out $-300 \mathrm{~m}$ from the creek. Zollweg and Wood (1993) postulated that the Rush Peak fault steps to the south and continues eastward as the Goodrich Creek fault, and discussed equivocal evidence of faulting in alluvium where this strand crosses Goodrich Creek. I examined this fault trace and agree that the active trace of the Rush Peak fault probably branches southward and eastward as the Goodrich Creek fault. The Goodrich Creek fault has the same fresh morphology as the Rush Peak fault, although the evidence for late Quaternary faulting at Goodrich Creek is uncertain. The Goodrich Creek fault continues eastward as a prominent break in slope almost to the Wieser River, just north of Goodrich. Transfer of late Quaternary activity to the Goodrich Creek fault is also supported by the subdued geomorphology of the range front of the Cuddy Mountains between Cow Creek and Goodrich Creek. This presumably less active northeasterly-trending branch of the Rush Peak fault appears to have been abandoned.

The westward extent of Quaternary activity on the Rush Peak fault is also problematic, because the fault also splays into Y-shaped branches at its western end. Between Camp Creek and Little Pine Creek, the Rush Peak fault splinters into several short northwest-and west-northwest-trending splays. However, west of Little Pine Creek, the most recent fault activity appears to be confined to the roughly east-west-trending southern arm of the " $Y$ ". The northwest-trending splay that defines the southern flank of the Cuddy Mountains has less evidence of recent activity than the southern arm, and appears to have been abandoned. Thus the most recent activity appears to be restricted to the roughly east-west-trending traces of the Rush Peak fault. This orientation is unusual in the context of most other active Basin and Range structures in the region, which generally trend north or northwest.

The total length of Quaternary activity along the Rush Peak fault is not well constrained.

Zollweg and Wood (1993) describe scarps in Quaternary deposits along the central section of the Rush Peak fault between Camp Creek and Deer Creek, and I observed probable fault scarps $2 \mathrm{~km}$ further east at Cow Creek, for a total length of 9 $\mathrm{km}$. Fault scarps have not been observed in the field along the splays at both ends of the fault zone, but these traces have similar geomorphic expression on aerial photographs, so I include them in the active fault length of the Rush Peak fault. Inclusion of these splays (including the Goodrich Creek fault) adds about $19 \mathrm{~km}$ to the active length of the Rush Peak fault, for a total probable Quaternary length of $28 \mathrm{~km}$. Zollweg and Wood (1993) measured a length of $12 \mathrm{~km}$ for the central portion of the Rush Peak fault, and a potential length of $23 \mathrm{~km}$ if the Goodrich Creek fault and northwest-trending splays at the western end are included. 


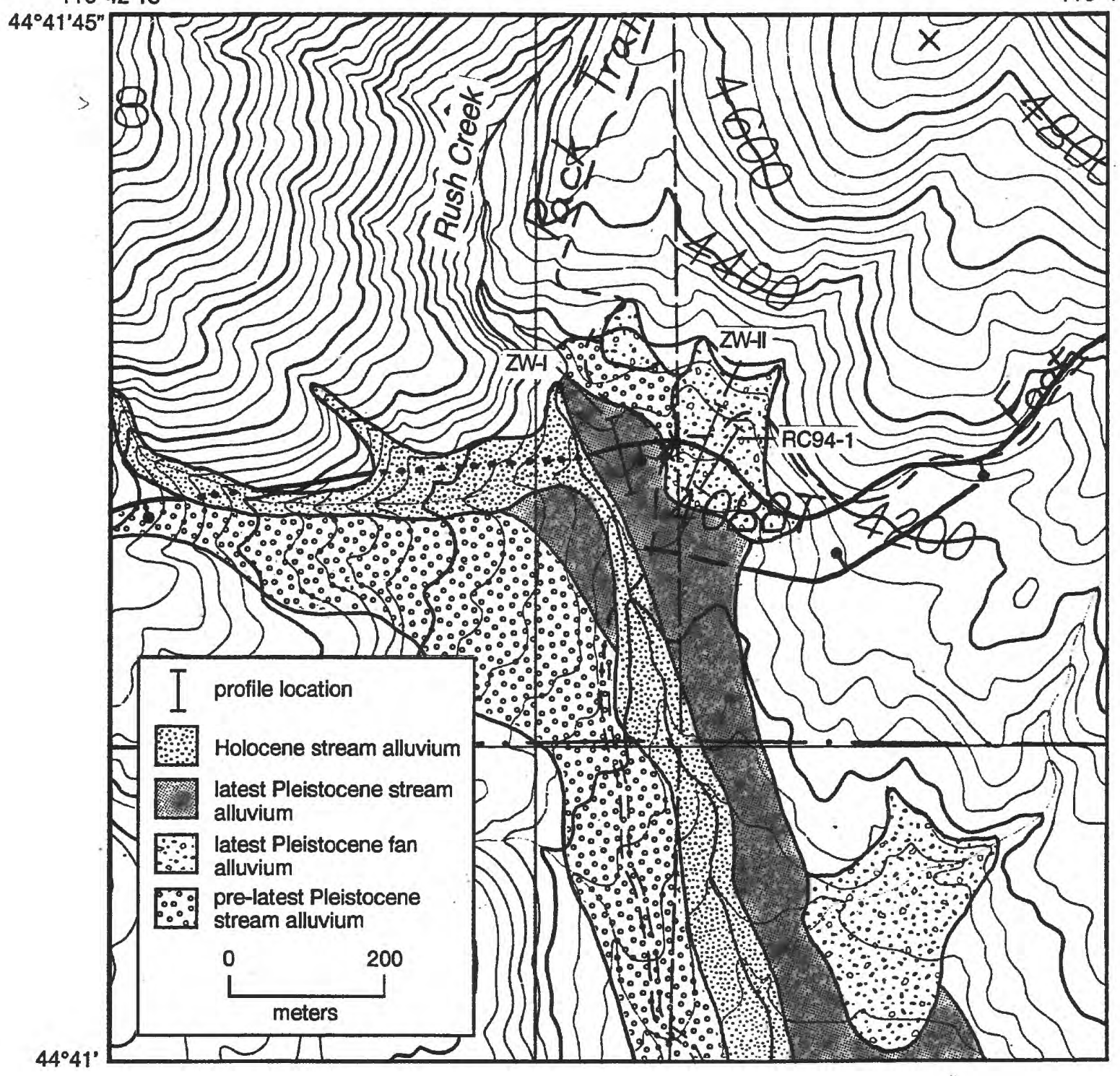

FIGURE 7. Surficial geologic map of the Rush Peak fault at Rush Creek; see figure 6 for location. Unshaded areas are Tertiary and older bedrock. Base is from U.S. Geological Survey Rush Peak, ID, 7.5 minute quadrangle. 
Zollweg and Wood (1993) used a late Cenozoic slip rate of $0.04 \mathrm{~mm} / \mathrm{yr}$, a fault length of $12 \mathrm{~km}$, and a distance of $18 \mathrm{~km}$ to Brownlee Dam to assess the earthquake hazard posed by the Rush Peak fault to hydropower structures on the Snake River. My assessment suggests a higher latest Pleistocene slip rate $(0.2-0.5 \mathrm{~mm} / \mathrm{yr})$, a longer fault length $(28 \mathrm{~km})$, and a shorter distance to Brownlee Dam $(13 \mathrm{~km})$. Such differences should be considered in future assessments of maximum credible earthquake magnitude, peak horizontal ground accelerations, and recurrence intervals of future large earthquakes on the Rush Peak fault.

\section{OREGON STUDY AREA Grande Ronde Valley Fault Zones}

The Grande Ronde Valley is a structurally controlled intermontane basin in northeastern Oregon (fig. 1). Previous work in the valley has shown that the eastern and western margins of the valley (fig. 9) are controlled by northwest-trending normal fault zones (e.g., Walker and MacLeod, 1991) that have been active in the late Cenozoic (Barrash and others, 1980). Several reports have focused on the earthquake potential of these structures (U.S. Army Corps of Engineers, 1983; Geomatrix Consultants, 1989, 1995; Simpson and others, 1993; Pezzopane, 1993). The city of $\mathrm{La}$ Grande, which is the county seat and major population center of Union County, is located along the western margin of the Grande Ronde Valley. Near La Grande, the valley is controlled by the $-50-\mathrm{km}$ long West Grande Ronde Valley fault zone (WGRVFZ), which Simpson and others (1993) break into 5 segments on the basis of fault geometry and recency of activity. They used similar criteria to break the $-40-\mathrm{km}$-long East Grande Ronde Valley fault zone (EGRVFZ) on the east side of the Grande Ronde Valley into three segments. These segments have been retained in the following discussions. However, delineation of earthquake segments, structural entities that act independently during large surface-rupturing earthquakes, ordinarily requires detailed fault trench investigations. Such studies have not been performed in this region, so until detailed investigations are conducted, the fault segments of Simpson and others
(1993) perhaps should be referred to as fault sections (Haller and others, 1993). Work in the present study was concentrated on the WGRVFZ in the immediate vicinity of the city of $\mathrm{La}$ Grande, and along a short portion of the EGRVFZ near Gasset Bluff, located 8-10 km north of the town of Cove. These two areas are discussed separately below.

\section{West Grande Ronde Valley Fault Zone}

Several traces of the WGRVFZ are located in the vicinity of the city of $\mathrm{La}$ Grande (fig. 10). The range front fault pattern here is complex, with an apparent left step in the fault trace that Simpson and others (1993) used to delineate the 10-km-long $\mathrm{La}$ Grande and 10-km-long Foothill segments of the WGRVFZ. Along both segments, the fault traces are marked by sharp breaks in slope along steep, high escarpments underlain by the Miocene Columbia River Basalt Group (Barrash and others, 1980; Walker and MacLeod, 1991). Simpson and others (1993) used such evidence to infer that the Foothills and La Grande segments are the most active of the five segments comprising the WGRVFZ. I have divided the following discussion of the WGRVFZ into three parts: (1) the northern end of the Foothill segment; (2) the northern end of the main trace of the $\mathrm{La}$ Grande segment; and (3) a previously undescribed eastern splay of the La Grande segment.

\section{Foothill Segment}

As described by Simpson and others (1993), the Foothill segment of the WGRVFZ is marked by alignment of topographic benches, steep range fronts, and springs. Most of the northern end of the segment is marked by a steep escarpment along Foothill Road, but a 5-m-high fault scarp offsets an old fluvial terrace a few hundred meters west of the Grandview Cemetery at the northern termination of the segment (fig. 10). A 5-m-thick section of the fluvial sediments that underlie the faulted terrace is exposed in an inactive gravel pit along Foothill Road a few hundred meters southeast of the cemetery. The gravel pit exposes well-sorted sands and gravels that must have been deposited by the main stem Grande Ronde River when the river flowed through the present location of the city of $\mathrm{La}$ 

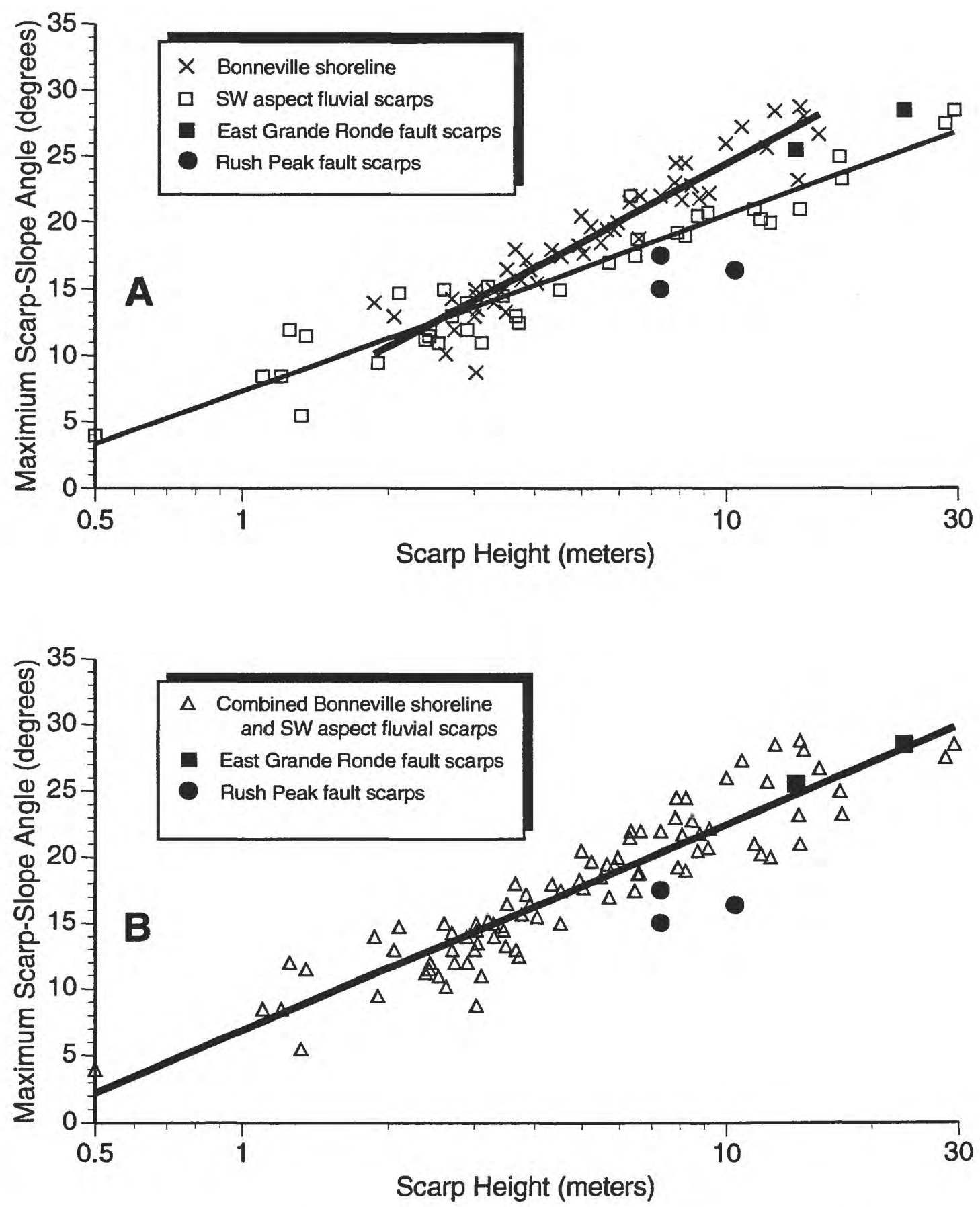

FIGURE 8. Plots of scarp height and scarp-slope angle values for all southwest-facing fault scarps obtained in this study. (A) Plot of southwest-facing scarps along the Rush Peak fault and the East Grande Ronde Valley fault zone and two $15 \mathrm{ka}$ reference linear regression lines for data from scarps of the Bonneville shoreline (heavier line) and southwest-facing fluvial scarps (lighter line) from central Idaho. (B) Plot of southwest-facing scarps along the Rush Peak fault and the East Grande Ronde Valley fault zone and single reference linear regression line for combined data from $15 \mathrm{ka}$ scarps of the Bonneville shoreline and southwest-facing fluvial scarps from central Idaho; see figure 2 for sources. Although the morphology of the Rush Peak scarps may indicate that they are slightly older than the 15 ka reference fluvial and shoreline scarps, the data probably fall within the error limits of this technique. The East Grande Ronde scarps are morphologically indistinguishable from the $15 \mathrm{ka}$ reference scarps. 


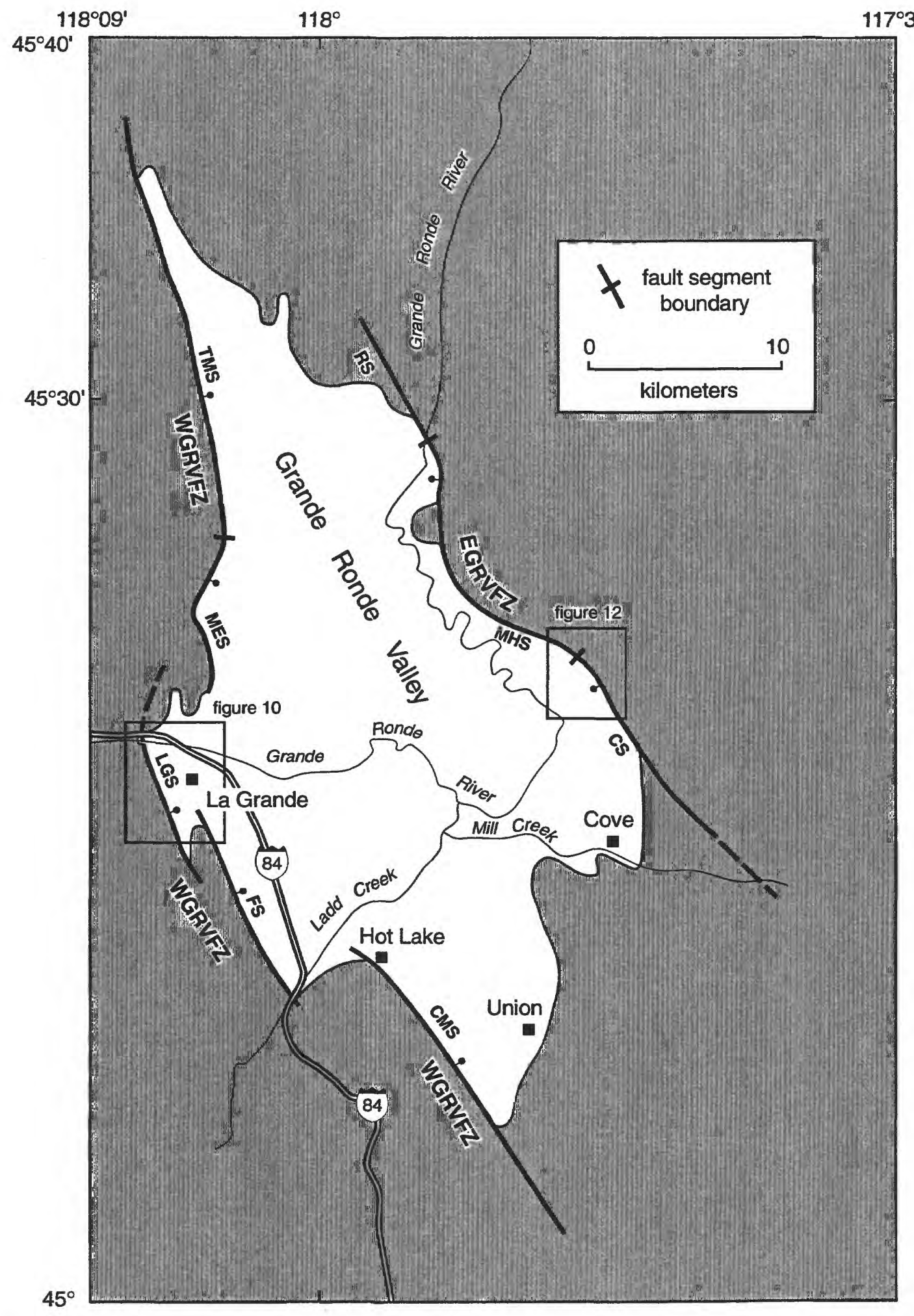

FIGURE 9. Map showing generalized traces of the West Grande Ronde Valley fault zone (WGRVFZ) and the East Grande Ronde Valley fault zone (EGRVFZ) in the Grande Ronde Valley of northeastern Oregon, modified from Simpson and others (1993) and Walker and MacLeod (1991). Fault segments are those described by Simpson and others (1993): (WGRVFZ) TMS - Thimbleberry Mountain segment; MESMount Emily segment; LGS - La Grande segment; FS - Foothill segment; CMS — Craig Mountain segment; (EGRVFZ) RS - Rhinehart segment; MHS-Mount Harris segment; and CS-Cove segment. Unshaded area is Quaternary valley-fill deposits. 


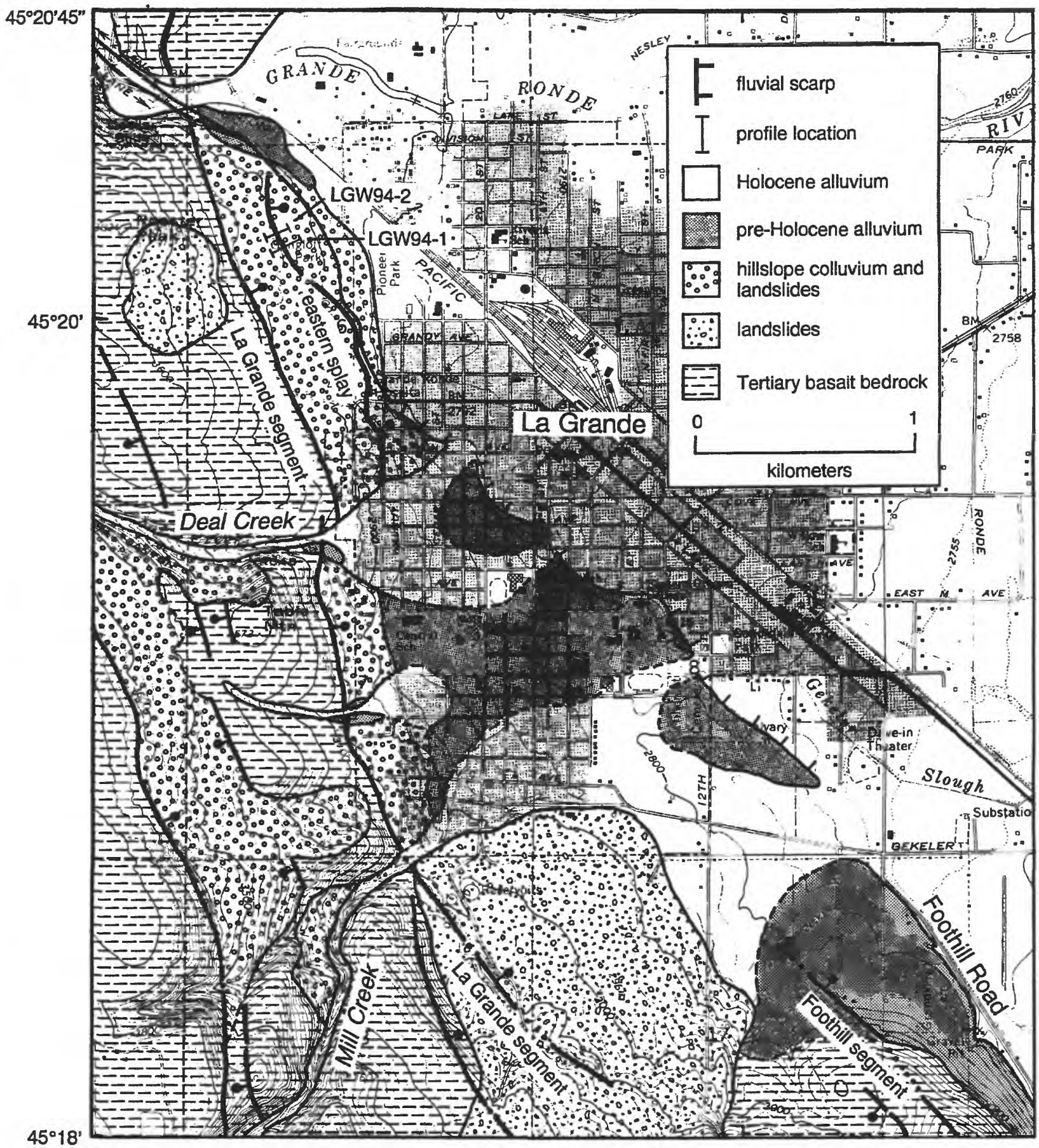

FIGURE 10. Surficial geologic map of West Grand Ronde Valley fault zone in vicinity of La Grande, Oregon; see figure 9 for location. 
Grande. A series of fluvial terrace risers that extends northwestward from the Grandview terrace marks the ancient course of the Grande Ronde River through the city. Correlation of these terrace remnants yields a paleosurface whose gradient (4-5 $\mathrm{m} / \mathrm{km}$ ) is the same as the present valley gradient of the Grande Ronde River.

The age of the faulted terrace at the northern end of the Foothill segment is unknown, but regional soils correlations are useful in estimating the age of this feature. A soil in the terrace sediments exposed in the Foothill Road gravel pit consists of 30- to 50-cm-thick $A$ and $A B$ horizons formed in loess, overlying a well developed 10- to 20-cm-thick Bt horizon and a 10- to 20-cm-thick stage $\mathrm{I}+\mathrm{Bk}$ horizon in the underlying sandy pebble gravel. Similar soil development was described by Crandell (1967) in pre-last-glacial-maximum deposits at Wallowa Lake, $-60 \mathrm{~km}$ to the east. Crandell (1967, p. C152) used the occurrence of Bt horizons to tentatively correlate his unit $\mathrm{T}$ drift with the Bull Lake glaciation in the Rocky Mountains. Glacial deposits related to this glaciation (oxygen-isotope stage 6 ) are thought to have been last deposited 140-150 ka (Pierce and others, 1976, 1982). Similar soil relations are apparent near McCall, Idaho, where Bt horizons are absent or only weakly developed in the youngest tills, but are moderately developed in early Wisconsin (oxygen-isotope stage 4) Williams Creek moraines, thought by Colman and Pierce (1986) to have formed about $60 \mathrm{ka}$. This age is consistent with the end of oxygen-isotope stage 4 (Chappell and Shackleton, 1986), a period of colder temperatures intermediate between the better expressed glacial deposits associated with stages 2 and 6 . An oxygenisotope stage 4 age also is consistent with soil development associated with TL-dated loess deposits in the eastern Snake River Plain (Forman and others, 1993). Several TL ages indicate a period of loess deposition $60-80 \mathrm{ka}$ at the Idaho National Engineering Laboratory, $450 \mathrm{~km}$ southeast of the Grande Ronde Valley (Forman and others, 1993). The Foothill Road fluvial sediments cannot be directly correlated with any of these deposits, but thick alluvial fills are commonly thought to have been deposited during or rapidly following glacial maximums in the western United States (Pierce and
Scott, 1982). The soils comparisons and the height of the Foothill Road terrace above the modern river $(-25 \mathrm{~m})$ indicate that these fluvial deposits probably are not latest Pleistocene in age, but rather were deposited during older glacial periods as much as 60-140 ka.

No scarp profiles were obtained on the scarp at the northern end of the Foothill segment, but where not disturbed by home and roadbuilding, the scarp is very subdued. At this location, latest movement on the Foothill segment does not appear to be latest Pleistocene in age, but further south, Simpson and others (1993) describe better evidence for late Pleistocene or Holocene movement along the mountain front south of the Grandview Cemetery. I found no evidence of Holocene fault movements during my brief reconnaissance of the northern part of the Foothill segment, but the steep range-front morphology and scarps in older alluvial deposits indicates a late Pleistocene age $(<60-140 \mathrm{ka})$ for latest movement on this part of the WGRVFZ.

\section{La Grande Segment}

As with the Foothill segment, the La Grande segment is best expressed as a series of steep, linear escarpments in the vicinity of the city of La Grande (fig. 10). In a few places along the La Grande segment, short fault scarps are preserved in alluvial-fan deposits near canyon mouths. With the exception of a small (1- to 2-m-high) possible fault scarp in young alluvium at the mouth of Deal Creek, most scarps are restricted to pre-Holocene(?) fan and terrace remnants that lie $5-10 \mathrm{~m}$ above the grade of modern drainages. Two- to five-meter-high scarps in pre-Holocene alluvial deposits are located at the mouth of Deal Creek and at the mouth of an unnamed drainage $0.8 \mathrm{~km}$ south of Deal Creek (Simpson and others, 1993). Larger scarps on landslide deposits are located south of the mouth of Mill Creek. Fault-scarp heights are difficult to measure in these older deposits, but offsets of about $20 \mathrm{~m}$ are apparent on topographic maps.

The ages of offset Quaternary deposits on the $\mathrm{La}$ Grande segment are unknown. No exposures of offset fan alluvium were observed at canyon mouths, but the restriction of these deposits in ter- 
races and fans 5-10 $\mathrm{m}$ above modern stream level indicate that they are probably late Pleistocene in age (Simpson and others, 1993). A small, short scarp in a younger, probably Holocene fan that lies $<5 \mathrm{~m}$ above stream level at the mouth of Deal Creek may represent a younger faulting event, but the fan surface is very bouldery and the site has been disturbed by roadbuilding. No other examples of scarps were found in similar deposits along the La Grande segment between Mill Creek and the Grande Ronde River, so the apparent young fault scarp at Deal Creek may represent young alluvium draped over a pre-existing fault scarp. Thus most evidence along the La Grande segment points to a late Pleistocene age for the most recent faulting event along this part of the WGRVFZ. The higher scarps in older deposits, however, are clear evidence of recurrent movement in the Quaternary. The age of the large landslide south of Mill Creek is unknown, but the large scarps located on this deposit are the result of numerous faulting events and thus suggest that this deposit is probably middle Pleistocene in age or older.

\section{Eastern Splay}

A prominent, $1.5-\mathrm{km}$-long fault scarp lies a few hundred meters east of the main trace of the La Grande segment northwest of the city of La Grande (fig. 10). The origin of this feature is somewhat enigmatic, because despite its prominence in the landscape, apparently it was not recognized as a fault scarp in previous investigations (Barrash and others, 1980; Simpson and others, 1993). This feature may have been mistaken for a fluvial escarpment or part of a landslide headscarp, but it consists of several straight segments and is semiparallel to the adjacent range front. In addition, the scarp cuts steeply across old colluvial/landslide deposits with a gradient of about $55 \mathrm{~m} / \mathrm{km}$, which is more than 5 times steeper than the gradient of older terrace treads and the present channel of the Grande Ronde River near La Grande. In addition, no evidence of sandy alluvium was found along the scarp, as might be expected if this feature was cut by stream erosion. Several recent excavations in the offset deposits along the highway downslope from the scarp showed $0.5-1 \mathrm{~m}$ of silty sediment (loess?) overlying angular and subangular basalt cobbles and boulders in a muddy matrix; such sediments are consistent with the interpretation that these are landslide deposits shed off the high escarpment west of the city. Landslide deposits and at least one large landslide headscarp are located a couple of hundred meters upslope on the flank of the mountain above these faulted deposits (fig. 10).

The age of the deposits offset by the eastern splay is unknown. However, the relatively subdued hummocky topography that characterizes the surface of these deposits suggests that they are not very young. In addition, several small, poorly exposed remnants of fluvial gravels are inset into the landslide deposits north of the eastern splay (fig. 10). The fluvial sediments are preserved in at least two terraces; the higher terrace lies as much as $40 \mathrm{~m}$ above the nearby Grande Ronde River, and the lower terrace may project to the faulted Grandview Cemetery terrace along Foothill Road. If the soil comparisons discussed above are reasonable, then the landslide must at a minimum be older than the proposed 60-140 ka age of the Grandview Cemetery terrace and is probably substantially older. Thus a middle Pleistocene or older age is reasonable for these deposits.

Despite the antiquity of the offset landslide deposits, the age of faulting along the eastern splay probably is similar to the age of faulting along the main trace of the La Grande segment. A latest Pleistocene age is supported by limited scarp-morphology data. Two scarp profiles show that the eastern splay is 11-12 m high, has 7-8 $\mathrm{m}$ of surface offset, and has maximum scarp-slope angles of $24^{\circ}-27^{\circ}$ (table 2). The surface-offset measurements indicate that this scarp was formed during several surfacefaulting events, and a comparison of these scarpmorphology parameters to fluvial scarps with similar northeast aspect in central Idaho and the Bonneville shoreline in northern Utah indicates that the fault scarps are morphologically similar to the $15 \mathrm{ka}$ reference scarps (fig. 11). The apparent latest Pleistocene morphologic age of the La Grande scarps is in agreement with the fact that the scarp has been eroded and/or buried by Holocene alluvium at its southern end (fig. 10). The exact relationship between the eastern splay and the mountainfront trace of the La Grande segment is unknown, 
but this splay is too short to be an independent segment, so they probably have moved synchronously in the late Pleistocene. If true, then the limited scarp-morphology data from the eastern splay indicates that one or more surface-faulting events have occurred on the $\mathrm{La}$ Grande segment of the WGRVFZ in the last $15 \mathrm{ka}$.

\section{East Grande Ronde Valley Fault Zone}

Simpson and others (1993) used fault geometry and recency of activity to break the $-40-\mathrm{km}$ long East Grande Ronde Valley fault zone (EGRVFZ) into three segments (fig. 9). From north to south, these are the Rhinehart, Mount Harris, and Cove segments. Most of my work on the EGRVFZ was focused on the northern end of the 15-km-long Cove segment in the vicinity of Gasset Bluff (fig. 12). Simpson and others (1993) discussed the occurrence of small (typically $<3 \mathrm{~m}$ ) scarps on late Pleistocene alluvium near the heads of fans at several unnamed canyon mouths along the Cove segment, and concluded that this was the most active part of the EGRVFZ. I did not evaluate the other segments, but I found evidence of faulting restricted to older, dissected alluvial-fan remnants that lie several meters above the modern drainages at the northern end of the Cove segment. No exposures of these deposits were seen, but their surface expression indicated a substantial component of loess on their surfaces, and a larger fraction of boulder-sized clasts than the fans related to the present drainages. These differences imply that the older fans were deposited under significantly different climatic conditions than the youngest (Holocene) fans. At least five deposits with similar characteristics are present at canyon mouths beneath Gasset Bluff (late Pleistocene fan alluvium on fig. 12). Most of these deposits retain lobate shapes that may be indicative of deposition as large debris flows, which would be consistent with the presence of larger clast sizes in these deposits. Because they still retain such morphology and are directly adjacent to and inset by the modern drainages $<10 \mathrm{~m}$, they are probably late Pleistocene in age.

These older fans are best preserved along the Cove segment below Gasset Bluff, a significant topographic feature formed by several coalescing landslide headscarps. Large landslide deposits from these headscarps underlie the reentrant in the mountain front at the northern end of the Cove segment (fig. 12). Where not covered by younger alluvium, these deposits still retain the hummocky topography that is characteristic of most landslides. Several secondary landslide headscarps are present on these lower landslide deposits; these features may explain the somewhat more complicated fault traces mapped by Simpson and others (1993) at the northern end of the Cove segment (compare their fig. 3-1 with fig. 12).

Profiles were measured across two fault scarps in the vicinity of Gasset Bluff. These scarps are developed on steep, probable late Pleistocene fan surfaces at the mouths of two unnamed canyons (fig. 12). These two scarps are $14-23 \mathrm{~m}$ high, but surface offsets are substantially smaller $(6-11 \mathrm{~m})$ because of the steepness of the original slopes (table 2). These surface-offset measurements indicate that the scarps are the result of several surface-faulting earthquakes. The morphology of the EGRVFZ scarps is indistinguishable from the morphology of 15 ka scarps in central Idaho and Utah (fig. 8), so the scarps may be latest Pleistocene in age. This age is consistent with the restriction of scarps to probable late Pleistocene deposits at the northern end of the Cove segment.

Thus my limited field studies generally agree with the assessments of Simpson and others (1993) that late Quaternary faulting in the Grande Ronde Valley is restricted to probable late Pleistocene faulting on the $\mathrm{La}$ Grande and Foothills segments of the West Grande Ronde Valley fault zone and the Cove segment of the East Grande Ronde Valley fault zone. Fault scarps on these two segments are restricted to deposits no younger than the latest Pleistocene, and yield scarp-profile data that are morphologically indistinguishable. 

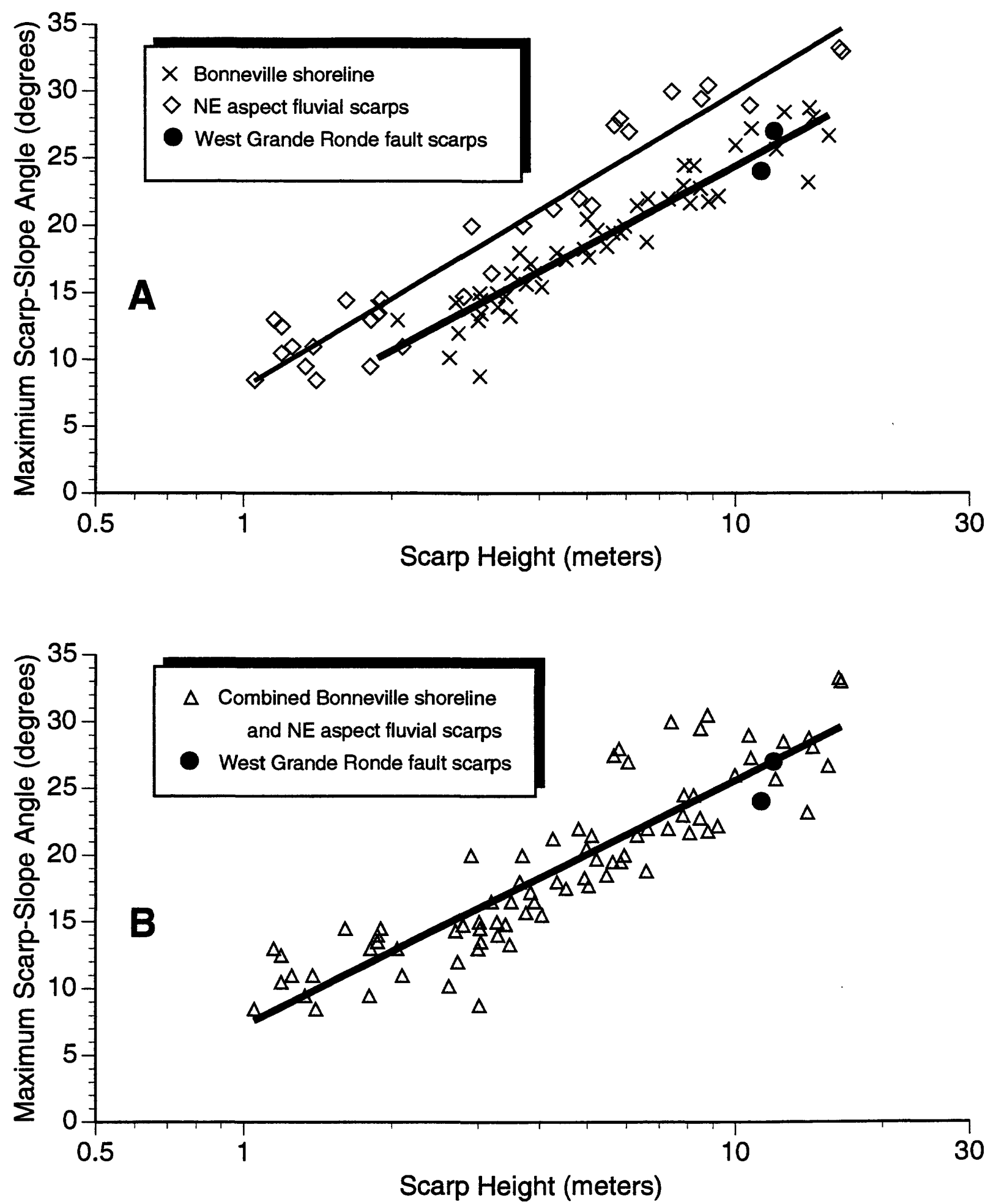

FIGURE 11. Plots of scarp height and scarp-slope angle values from eastern splay of La Grande segment of the West Grand Ronde Valley fault zone. (A) Plot of northeast-facing fault scarps and two $15 \mathrm{ka}$ reference linear regression lines for data from scarps of the Bonneville shoreline and northeast-facing fluvial scarps from central Idaho. (B) Plot of northeast-facing fault scarps and single reference linear regression line for combined data from $15 \mathrm{ka}$ scarps of the Bonneville shoreline and northeast-facing fluvial scarps from central Idaho; see figure 2 for sources. Note that West Grande Ronde scarps are morphologically indistinguishable from the $15 \mathrm{ka}$ reference scarps. 


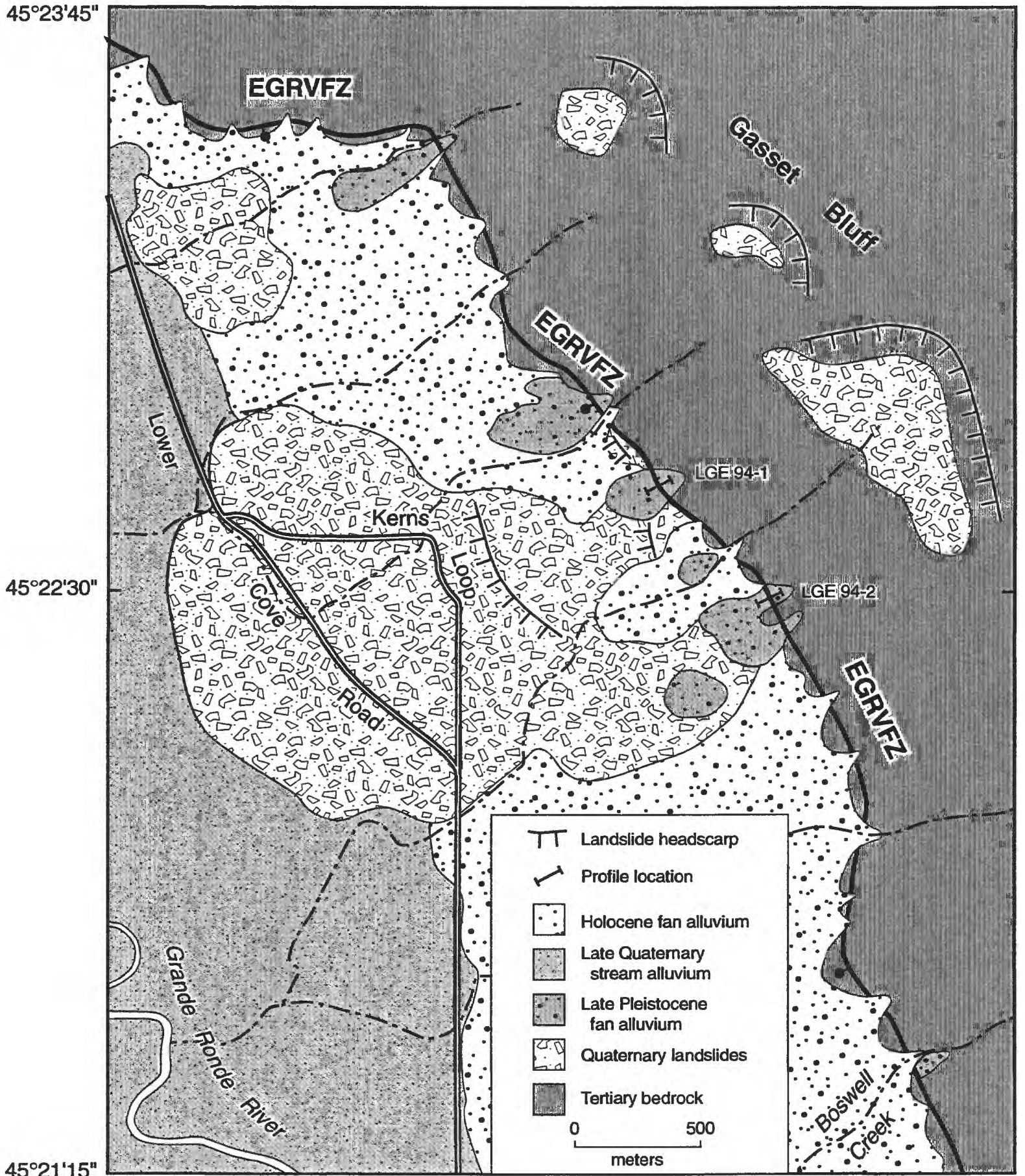

FIGURE 12. Surficial geologic map of East Grand Ronde Valley fault zone (EGRVFZ) in the vicinity of Gasset Bluff, 8-10 km north of Cove, Oregon; see figure 9 for location. 


\section{REFERENCES}

Armstrong, R.L., Taubeneck, W.H., and Hales, P.O., 1977, $\mathrm{Rb}-\mathrm{Sr}$ and $\mathrm{K}-\mathrm{Ar}$ geochronometry of Mesozoic granitic rocks and their $\mathrm{Sr}$ isotope composition, Oregon, Washington, and Idaho: Geological Society of America Bulletin, v. 88, p. 397-411.

Barrash, W., Bond, J.G., Kauffman, J.D., and Ventkatakrishnan, R., 1980, Geology of the La Grande area, Oregon: Oregon Department of Geology and Mineral Industries, Special Paper 6, 47 p., 5 plates, scale 1:24,000.

Bovis, M.J., 1982, Uphill-facing (antislope) scarps in the Coast Mountains, southwest British Columbia: Geological Society of America Bulletin, v. 93, p. 804-812.

Brooks, H.C., and Vallier, T.L., 1978, Mesozoic rocks and tectonic evolution of eastern Oregon and western Idaho, in Howell, D.G., and McDougall, K.A., eds., Mesozoic paleogeography of the Western United States: Society of Economic Paleontologists and Mineralogists, Pacific Coast Paleogeographic Symposium 2, p. 133-145.

Bucknam, R.C., and Anderson, R.E., 1979, Estimation of fault-scarp ages from a scarpheight-slope-angle relationship: Geology, v. 7, p. 11-14.

Carrara, P.E., and Doerner, J.P., 1996, Pinedale glaciation and the timing of deglaciation in the West Mountains of Idaho: American Quaternary Association Program and Abstracts, 14th Biennial Meeting, p. 156.

Chappell, J., and Shackleton, 1986, Oxygen isotopes and sea level: Nature, v. 234, p. 137140.

Clague, J.J., and Evans, S.G., 1994, A gravitational origin for the Hell Creek "fault", British Columbia: Geological Survey of Canada, Current Research 1994-A, p. 193-200.
Colman, S. M., and Pierce, K.L., 1986, Glacial sequence near McCall, Idaho-Weathering rinds, soil development, morphology, and other relative-age criteria: Quaternary Research, v. 25, p. 25-42.

Costa, J.E., and Schuster, R.L., 1991, Documented historical landslide dams from around the world: U.S. Geological Survey Open-File Report 91-239, 486 p.

Crandell, D.W., 1967, Glaciation at Wallowa Lake, Oregon: U.S. Geological Survey Professional Paper 575-C, p. C145-153.

Currey, D.R., 1990, Quaternary paleolakes in the evolution of semidesert basins, with special emphasis on Lake Bonneville and the Great Basin, U.S.A.: Paleogeography, Paleoclimatology, Paleoecology, v. 76, p. 189214.

Fitzgerald, J.F., 1981, Geology and basalt stratigraphy of the Weiser embayment, west-central Idaho: Moscow, University of Idaho, Ph.D. thesis, 119 p., 1 plate, scale 1:250,000.

Forman, S.L., Smith, R.P., Hackett, W.R., Tullis, J.A., and McDaniel, P.A., 1993, Timing of Late Quaternary glaciations in the western United States based on the age of loess on the eastern Snake River Plain, Idaho: Quaternary Research, v. 40, p. 30-37.

Geomatrix Consultants, 1989, Final seismotectonic evaluation for Mann Creek dam site (Idaho) and Mason Creek dam site (Oregon): unpublished report prepared for U.S. Bureau of Reclamation, 118 p., 4 plates.

Geomatrix Consultants, 1995, Final report seismic design mapping State of Oregon: unpublished report prepared for Oregon Department of Transportation, 507 p., 11 plates. 
Gilbert, J.D., Piety, L., and Laforge, R.C., 1990,

Seismotectonic study, Black Canyon diversion dam and reservoir, Boise project, Idaho:

Seismotectonic Report 90-2, U.S. Bureau of

Reclamation, 40 p.

Haller, K.M., Machette, M.N., and Dart, R.L., 1993, Maps of major active faults, Western Hemisphere, International Lithosphere Program (ILP) Project II-2-Guidelines for U.S. database and map: U.S. Geological Survey OpenFile Report 93-338, 45 p.

Hanks, T.C., and Wallace, R.E., 1985, Morphological analysis of the Lake Lahonton shoreline and beachfront fault scarps, Pershing County, Nevada: Seismological Society of America Bulletin, v. 75, p. 835-846.

Hooper, P.R., and Conrey, R.M., 1989, A model for the tectonic setting of the Columbia River basalts eruptions, in Reidel, S.P., and Hooper, P.R., eds., Volcanism and tectonism in the Columbia River basalt province: Geological Society of America Special Paper 239, 293-305.

Izett, G.A., and Obradovich, J.D., 1994, ${ }^{40} \mathrm{AR} /{ }^{39} \mathrm{Ar}$ age constraints for the Jaramillo normal subchron and the Matuyama-Bruhnes geomagnetic boundary: Journal of Geophysical Research, v. 99, p. 2925-2934.

Kinoshita, W.T., 1962, A gravity survey of part of the Long Valley district, Idaho: U.S. Geological Survey Open File Report, 11 p.

Mann, G.M., and Meyer, C.E., 1993, Late Cenozoic structure and correlations to seismicity along the Olympic-Wallowa Lineament, northwest United States: Geological Society of America Bulletin, v. 105 , p. 853-871.

McCalpin, J.P., and Irvine, J.R., 1995, Sackungen at the Aspen Highlands ski area, Pitkin County, Colorado: Environmental and Engineering Geoscience, v. 1, p. 277-290.
Mitchell, V.E., and Bennett, E.H., 1979, Geologic map of the Baker quadrangle, Idaho: Idaho Bureau of Mines and Geology Geologic Map Series map, scale 1:250,000.

Morrison, R.B., 1991, Introduction, in Morrison, R.B., ed., Quaternary nonglacial geologyConterminous U.S.: Boulder, Colorado, Geological Society of America, The Geology of North America, v. K-2, p. 1-12.

Morton, D.M., Campbell, R.H., Jibson, R.W., Wesson, R.L., and Nicholson, C., 1989, Ground fracturing and landsliding produced by the July 8, 1986, North Palm Springs earthquake, in Sadler, P.M., and Morton, D.M., eds., Landslides in a semi-arid environment, with emphasis on the inland valleys of southern California: Inland Geological Society, Publication 2, p. 301-322.

Othberg, K.L., 1982, Surficial geologic map of the Baker quadrangle, Idaho: Idaho Bureau of Mines and Geology Surficial Geology Map Series map, scale 1:250,000.

Pezzopane, S.K., 1993, Active faults and earthquake ground motions in Oregon: Eugene, University of Oregon Ph.D. thesis, 208 p.

Pierce, K.L., and Colman, S.M., 1986, Effect of height and orientation (microclimate) on geomorphic degradation rates and processes, lateglacial terrace scarps in central Idaho: Geological Society of America Bulletin, v. 97, p. $869-885$.

Pierce, K.L., and Scott, W.E., 1982, Pleistocene episodes of alluvial-gravel deposition, southeastern Idaho, in Bonnichsen, B., and Breckenridge,R.M., eds., Cenozoic geology of Idaho: Idaho Bureau of Mines and Geology Bulletin 26, p. 685-702. 
Pierce, K.L., Obradovich, , J.D., and Friedmoan, I., 1976, Obsidian hydration dating and correlation of Bull Lake and Pinedale glaciations near West Yellowstone, Montana: Geological Society of America Bulletin, v. 87, p. 703-710.

Pierce, K.L., Fosberg, M.A., Scott, W.A., Lewis, G.C., and Colman, S.M., 1982, Loess deposits of southeastern Idaho, in Bonnichsen, B., and Breckenridge,R.M., eds., Cenozoic geology of Idaho: Idaho Bureau of Mines and Geology Bulletin 26, p. 717-725.

Radbruch-Hall, D.H., Varnes, D.J., and Savage, W.Z., 1976, Gravitational spreading of steepside ridges ("sackung") in Western United States: International Association of Engineering Geology Bulletin, no. 14, p. 2335.

Reidel, S.P., and Hooper, P.R., eds., 1989, Volcanism and tectonism in the Columbia River basalt province: Geological Society of America Special Paper 239, 379 p.

Schmidt, D.L, and Mackin, J.H., 1970, Quaternary geology of the Long and Bear Valleys, west-central Idaho: U.S. Geological Survey Bulletin 1311-A, 22 p.

Scott, W.E., McCoy, W.D., Shroba, R.R., and Ruben, M., 1983, Reinterpretation of the exposed record of the last two lake cycles of Lake Bonneville, Western United States: Quaternary Research, v. 20, p. 261-285.

Simpson, G.D., Hemphill-Haley, M.A., Wong, I.G., Bott, J.D.J., Silva, W.J., and Lettis, W.R., 1993, Seismotectonic interpretation Unity Dam, Burnt River Project, and Thief Valley Dam, Baker Project, northeastern Oregon: unpublished Final Report prepared for U.S. Bureau of Reclamation, 97 p., 2 plates.
Solonenko, V.P., 1977, Landslides and collapses in seismic zones and their prediction: International Association of Engineering Geology Bulletin, no. 15, p. 4-8.

U.S. Army Corps of Engineers, 1983, The Dalles and John Day Lakes-Earthquake and fault study: U.S. Department of the Army Design Memorandum no. 26, 66 p.

Vallier, T.L., and Brooks, H.C., eds., 1987, Geology of the Blue Mountains region of Oregon, Idaho, and Washington-the Idaho Batholith and its border zone: U.S. Geological Survey Professional Paper 1436, 196 p.

Varnes, D.J., Radbruch-Hall, D.H., and Savage, W.Z., 1989, Topographic and structural conditions in areas of gravitational spreading of ridges in the Western United States: U.S. Geological Survey Bulletin 1496, 28 p.

Walker, G.W., and MacLeod, N.S., 1991, Geologic map of Oregon: U.S. Geological Survey special map, scale 1:500,000.

Zollweg, J.E., and Wood, S.H., 1993, Faulting relationships, seismicity, design earthquakes, and peak ground accelerations at hydroelectric facilities in Hells Canyon of the Snake River, Idaho-Oregon: Unpublished report prepared for Idaho Power Company, 158 p., 3 plates. 